\title{
Finansal Okuryazarlık, Risk Alma Eğilimi ve Belirsizliğe Karşı Tolerans iliş̧kisi: Batı Akdeniz Girişimcileri Üzerine Bir Araştırma ${ }^{1}$
}

\author{
Funda Kıran² \\ Özlem Çetinkaya Bozkurt ${ }^{3}$
}

\author{
Finansal Okuryazarlık, Risk Alma Eğilimi ve Belirsizliğe \\ Karşı Tolerans i̇lişkisi: Batı Akdeniz Girişimcileri Üzerine \\ Bir Araştırma
}

Öz

Finansal işlemler gün geçtikçe daha karmaşık hale gelmektedir. İşlemlerle ilgili risk ile sorumluluk sürekli artmaktadır ve alınan yanlış kararlar hem mikro hem de makro ölçekte etki sağlamaktadır. Bu durumlar bireylerin sahip olması gereken finansal okuryazarlığın günümüzdeki önemini arttırmıştır. Girişimciler açısından bakıldığında ise iş fikrinin ortaya atılmasından işin kurulumuna, kurulumundan yönetimine kadar geçen her süreçte finansal okuryazarlık becerisi bir gereklilik halini almıştır. Bu araştırmada da girişimciler açısından finansal okuryazarlık konusu incelenmiş ve Batı Akdeniz bölgesinde faaliyet gösteren girişimcilerin finansal okuryazarlık seviyesi ve alt boyutlarıyla, girişimci özelliklerinden olan risk alma eğilimi ve belirsizliğe karşı tolerans değişkenlerinin ilişkisini ortaya çıkartmak amaçlanmıştır. Anket tekniği ile verilerin toplandığı araştırmanın sonunda finansal okuryazarlık, finansal bilgi ve finansal tutum seviyeleriyle girişimcilik özelliklerinden risk alma eğiliminin ve belirsizliğe karşı toleransın pozitif yönlü hareket ettiği tespit edilmiştir.

Anahtar Kelimeler: Finansal Okuryazarlık, Risk Alma Eğilimi, Belirsizliğe Karşı Tolerans, Girişimci
Relationship between Financial Literacy, Propensity to Take Risk and Tolerance of Ambiguity: A Research on Western Mediterranean Entrepreneurs

\section{Abstract}

Financial transactions are becoming more complex day by day. Risk and responsibilities about transactions are increasing continuously and wrong financial decisions' effect micro and macro level. These situations have increased the today's importance of financial literacy that individuals should have. From the perspective of the entrepreneurs, financial literacy skills become a necessity in every process which consists of the establishment of the business idea, installation and management. In this study, financial literacy was examined from the point of entrepreneurs. Revealing the relationship between Western Mediterranean region entrepreneurs' financial literacy - sub dimensions and propensity to take risk - tolerance of ambiguity is aimed. The study whose data were obtained by using questionnaires, determined that propensity to take risk and tolerance of ambiguity which are entrepreneurship characteristics move the same direction with financial literacy, financial information and financial attitude levels.

Keywords: Financial Literacy, Propensity to Take Risk, Tolerance of Ambiguity, Entrepreneur

\section{Giriş}

Finansal kavramlar hakkında temel bilgi seviyesine sahip olan, temel matematiksel hesaplamaları yapabilen, gelirlerini ve giderlerini bütçe ile takip eden ve giderlerinin gelirlerini aşmaması için önlemler alan, geleceği düşünen, hedefler koyan, bu hedeflere ulaşmak için çaba harcayan, düzenli olarak finansal durumunu kontrol eden, güncel haberlerin takibini yapan ve geleceğe dair öngörüde bulunabilen bireyler olan finansal okuryazarlar son dönemlerin ilgi çekici konusu olarak öne çıkmayı başarmıştır. Öyle ki dünya çapında ekonomik işbirliği alanında en önemli platformlardan biri olan, finansal konular hakkında tartışmaların olduğu ve işbirliklerinin

\footnotetext{
${ }^{1}$ Bu çalışma, Burdur Mehmet Akif Ersoy Üniversitesi, Sosyal Bilimler Enstitüsü, İ̧̧letme Yüksek Lisans Programında Prof. Dr. Özlem Çetinkaya Bozkurt danışmanlığında yürütülen ve Funda Kıran tarafından yazılan "Finansal Okuryazarlık, Risk Alma Eğilimi ve Belirsizliğe Karşı Tolerans İlişkisi: Batı Akdeniz Girişimcileri Üzerine Bir Araştırma” başlıklı 20.06.2019 tarihinde savunulan tezden üretilmiştir.

${ }^{2}$ Arş. Gör., Burdur Mehmet Akif Ersoy Üniversitesi Bucak İşletme Fakültesi, İşletme Bölümü. fkiran@mehmetakif.edu.tr, Yazar ORCID bilgisi: 0000-0002-6456-2497

${ }^{3}$ Prof. Dr. Burdur Mehmet Akif Ersoy Üniversitesi Bucak İşletme Fakültesi, İşletme Bölümü. ozlemcetinkaya@mehmetakif.edu.tr, Yazar ORCID bilgisi: 0000-0002-6218-2570
} 
yapıldığı G-20 zirvesinin 2015 yılı gündem maddelerinden biri finansal okuryazarlık olarak belirlenmiştir (Alkaya ve Yağlı, 2015: 586). Ayrıca Bianco ve Bosco (2000) tarafından finansal okuryazarlığın İngilizce bilmekle veya diğer bilim dallarında okuryazar olmakla eş öneme sahip olduğu dile getirilmiştir. Alan yazında da konu üzerinde çeşitli çalışmaların yapılmakta olduğu; işletmeler (Brown vd., 2006: 183), hane halkı (Atkinson ve Messy, 2012: 6; Bönte ve Filipiak, 2012: 3402; Disney ve Gathergood, 2013: 2247), yatırımcılar (Abreu ve Mendes, 2010: 518), mali müşavirler (Dağdelen, 2017) ve öğrenciler (Chen ve Volpe, 1998: 107; Beal ve Delpachitra, 2003: 69; Cude vd., 2006: 102; Temizel ve Bayram, 2011: 73; Ansong ve Gyensare, 2012: 126; Chinen ve Endo, 2012: 778; Louw vd., 2013: 439) gibi farklı örneklemler üzerinde çalışmaların yer aldığı görülmektedir. Fakat konunun girişimcilerin perspektifinden yeterince incelenmediğine inanılmaktadır. Her ne kadar finansal okuryazarlık ve girişimcilik niyeti ilişkisini sorgulayan çalışmalar alan yazında yer alsa da girişimciler üzerinde yapılan çalışma sayısının artmasında yarar görülmektedir. Çünkü tüketiciye oranla daha kritik kararlar veren, ekonomi, siyaset, sanat gibi birçok farklı alanı da etkileyen girişimcilerde; finansal okuryazarlık çok daha büyük öneme sahiptir. Finansal okuryazarlık bilgisiyle girişimciler; yetersiz sermaye nedeniyle karşılaştığı maliyeti, düzensiz para akışı sonucu oluşabilecek şirket içi krizleri, kur, faiz ve fiyat riskini ve buna benzer finansal açıdan vermiş olduğu kararlarda oluşabilecek problemleri elimine edebilecektirler. Ayrıca bilgi toplayan, gelişmeleri izleyen ve gelecekle alakalı tahmin yürüten finansal okuryazar girişimcilerin rakiplerine göre hesaplanmış risk alma oranlarının artacağı ve hem geleceğe dair ihtimalleri gözden geçirmesi hem de olağan dışı durumlara karşı aldığı tedbirler sayesinde belirsizliği daha yüksek seviyede tolere edebileceği düşünülmektedir. Bu doğrultuda yapılan çalışmada; girişimcilerin finansal okuryazarlık seviyesi ve finansal okuryazarlığın alt boyutları ile girişimcilerin risk alma ve belirsizliğe karşı tolerans özellikleri arasındaki ilişki sorgulanmıştır.

\section{Finansal Okuryazarlık Kavramı}

Konuyla ilgili alanyazın incelendiğinde görülmektedir ki finansal okuryazarlık ile ilgili net bir tanım bulunmamaktadır. Konu üzerinde çalışan araştırmacılar kavramı yorumlamış ve farklı şekillerde açıklamışlardır.

Türkiye'de finansal okuryazarlık ve finansal erişim konusunda farkındalık oluşturmak ve bu konuda olanakları genişletmek amacıyla bilinçlendirme çalışmaları yapan, eğitim imkânlarını sağlayan, araştırma yapan, konu ile alakalı yapılan uygulamalara destek veren ve politika üretilmesi hususunda çaba sarf eden Ekonomik Kalkınma ve İşbirliği Örgütü’nce (OECD) tanınan Finansal Okuryazarlık ve Erişim Derneği (FODER, 2018); finansal okuryazarlığı bireylerin para kullanımında ve para yönetiminde gerekli bilgiye sahip olma, bu bilgi ile değerlendirme yapma ve etkin karar verme becerisi olarak yorumlamıştır.

Uluslararası Finansal Eğitim Ağı (INFE) tarafında Ekonomik Kalkınma ve İşbirliği Örgütü’ne (OECD) hazırlanan raporda finansal okuryazarlık; finansal kararların alınabilmesi ve bireylerin finansal mutluluğa ulaşabilmeleri amacıyla gereken farkındalık, bilgi, beceri, tutum ve davranış bütünü biçiminde tanımlanmıştır (OECD INFE, 2011: 3).

Noctor ve diğerlerinin (1992) yapmıs olduğu tanıma göre ise, finansal okuryazarlık, bilinçli bir şekilde değerlendirme yapabilme ve paranın kullanımı ile yönetimine yönelik etkin kararlar alabilme yeteneğidir. Bu tanım Finansal Hizmetler Kurumu, Ulusal Sürekli Yetişkin Eğitim Enstitüsü, ANZ bankası, Avustralya yetişkin okuryazarlık konseyi ve birçok araştırma kuruluşu tarafından kabul edilmiştir (Alkaya ve Yağlı, 2015: 586). 
Wagland'a göre (2006'dan aktaran Er vd., 2014: 116) finansal okuryazarlık kavramı sadece finans konusunda bilgi edinip anlama, değerlendirme yapma ve karar alma prosedürünü kapsamamaktadır. Finansal okuryazarlar ayrıca, finansal kararlarla alakalı araştırma yapma, değerlendirme ve finansla alakalı konularda ortaya çıkan sorunları çözmek amacıyla kullanma becerilerine de sahip olmalıdır.

Finansal okuryazarlık bileşenleri hakkında da farklı sınıflandırmalar yapılmaktadır. Bu çalışmada da 4 kıtada 14 farklı ülkede uygulanarak kabul gören OECD tarafından oluşturulan finansal okuryazarlık ölçeğinin kullanılması dolayısıyla OECD’nin ayrımı önemsenmiş ve finansal okuryazarlığı oluşturan üç bileşen ele alınmıştır. Bu bileşenler: "finansal bilgi", "finansal tutum" ve "finansal davranış"tır.

Finansal bilgi; finans ve ekonomi ile ilgili haberlerin takibi, finansal ürün ve hizmetlerin karşılaştırılması ve bilinçli finansal kararlar alınması için gerekli olan yapıtaşlarından biridir (OECD, 2017: 15). Bütçeleme, tasarruf etme, yatırım yapma, sigorta, kredi, basit ve bileşik faiz hesaplaması, enflasyonun alım gücüne etkisi, risk - getiri ilişkisi, bilanço gibi temel kavram bilgisi bu grupta dikkate alınır (Alkaya ve Yağlı, 2015: 587; OECD, 2017: 15-16).

Finansal tutum bireylerin finans konusunda bilgisi olmasına rağmen harekete geçirici özelliği bulunması yönüyle finansal okuryazarlık kavramının bir bileşeni olarak ele alınmaktadır (OECD, 2017: 39). Bireylerin finans konusunda kısa ve uzun vadeli hedefler koyması ve düzenli aralıklarla bu hedefleri gözden geçirmesi (Öztürk, 2014: 14), parayı kullanırken gösterdiği özen, idareli harcama yapma ve tasarruf etme eğilimleri (OECD, 2017: 39) finansal tutum altında incelenmektedir.

Bireylerin finans durumunu ve mutluluğunu da onların uzun ve kısa dönemdeki finans konusunda göstermiş olduğu tepkileri yani davranışları belirler (OECD, 2017: 27-34). Bu yönüyle finansal davranış, finansal okuryazarlık bileşeni olarak ortaya çıkmaktadır. Bütçe kullanımı, finansal kararların sorumluluğunu üstlenme, karşılaştırma yaparak veya üzerinde düşünerek alışveriş yapma, faturaları zamanında ödeme, mali işleri takip etme gibi finansal kontrolleri gerçekleştirmek; birikim yapma, geçimini sağlama ve dış şoklarla yüzleşme, uzun vadeli hedeflere ulaşmak için çaba gösterme gibi finansal dayanıklılığı sağlayacak davranışlar ve finansal ürün seçiminde bilinçli davranmak finansal davranış üzerinde etkili olacaktır (OECD, 2017: 27-34).

\section{Girişimcilik, Risk Alma Eğilimi ve Belirsizliğe Karşı Tolerans}

Girişimcilik kavramının kökü incelendiğinde oldukça eski bir kavram olduğu hatta ortaçağa kadar uzanan bir geçmişe sahip olduğu görülmektedir. Kavram, iş dünyasında ise 18. yüzyılda ekonomist Richard Cantillon ile birlikte kullanılmaya başlanmıştır. Cantillon'a göre girişimci “henüz belirginleşmemiş bir bedelle satmak üzere üretim girdilerini ve hizmetlerini bugünden satın alan ve üreten kişi”" dir (Çelik vd., 2013: 33). Girişimcilik; iş dünyası terminolojisine girdiği ilk dönemlerde, sahip olunan bireysel sermaye ile iş kurma anlamında kullanılmıştır. Daha sonra ise akımlara göre girişimciliğin anlamı değişiklik göstermiştir. Klasik iktisatçılar girişimciliği oldukça dar anlamda kullanmışlar, iktisadi aktiviteler içerisinde önem kazanacak bir mana yüklememişlerdir. Klasik iktisatçılardan Jean Baptiste Say girişimciliği "üretim faktörlerini toparlayan kişi” olarak tanımlamıştır (Çelik vd., 2013: 33). Klasiklerin girişimciye vermiş oldukları anlam ise neoklasiklerle birlikte değişikliğe uğramıştır. Neoklasik akımının savunucularından biri olan Marshall'a göre girişimci, işletmesinin tüm sorumluluğunu üstlenen, emek ve sermaye öncelikli olmak üzere işletme içerisinde gerçekleşen kaynakları ve işlemleri kontrol eden, riskleri üstlenen, üretimin gerçekleşmesi için çaba gösteren bir yönetici ve iş görendir (İrmiş vd., 2010: 8). 
Girişimci ile yeniliği ilişkilendiren ilk isim ise Joseph Alois Schumpeter'dir. Schumpeter girişimciyi; üretim için gerekli olan kaynakları kullanarak farklı bir ürünü/hizmeti veya aynı ürünü/hizmeti farklı yöntemler kullanarak sunan kişi olarak tanımlamıştır (Çetindamar ve Fiş, 2007'den aktaran Fiş ve Wasti, 2009: 130-131). Günümüzde de halen girişimcilik ve girişimci hakkında yapılmış kesin bir tanım bulunmamaktadır (Çetinkaya Bozkurt, 2011: 5). Güncel tanımlamalardan örnek vermek gerekirse girişimcilik "bir birey veya birey grubunun; hangi kaynaklar elde bulundurulursa bulundurulsun, değer ve büyüme yaratmak için eşsiz, tek olma ve inovasyon yoluyla, gereksinimleri yerine getirecek fırsatları izlemek üzere düzenlenmiş güç ve imkânları kullandıkları süreç" (Coulter ve Robbins, 2003: 42) olarak tanımlanmıştır. Özgüner (2015: 149) ise oluşan fırsatları sezme, sezgileri düşlere çevirme, düşlerden projeler oluşturma, projeleri hayata dâhil etme ve projelerle birlikte ortaya çıkan zenginlikle bireylerin hayatını kolaylaştırma prosedürü şeklinde açıklamıştır. Brenkert'e (2009: 450) göre girişimci, ürünler ve hizmetler için yenilikçi ve yaratıcı fikirleri olan, yeni fırsatları ve değerleri geliştirebileceği bir kuruluş kuran veya bir kuruluş için çalışan (iç girişimcilik), bu süreçte riskler ve engeller ile karşılaşan kişidir.

Girişimcilerin öneminin anlaşılmasıyla birlikte, girişimcilerin özellikleri merak uyandırmış ve ortak özelliklerin olabileceği düşünülmüştür. Bu amaçla birçok araştırmacı veya kuruluş tarafından girişimcilik özellikleri üzerinde çalışılmıştır. Çalışma sonucunda da girişimcilerin sahip oldukları özellikler ile faaliyetleri arasında bir ilişki tespit edilmiştir (Hardy, 1999: 52; Pickle, 1964 aktaran Mc Clelland, 1987: 219; Hornaday ve Bunker, 1970 aktaran Mc Clelland, 1987: 219; Küçükaltan, 2009: 24). Yapılan çalışmalar farklı sınıflandırmalar kullanmış ve girişimcilik özellikleri bu yönüyle çeşitlenmiştir. Fakat literatürde en yaygın kullanılan girişimcilik özellikleri başarma ihtiyacı duyma, kontrol odağı, risk alma eğilimi, belirsizliğe karşı tolerans, kendine güven ve yenilikçiliktir (Koh, 1996: 13). Finansal okuryazarlık kavramının risk ve getiri üzerinde durması ve finansal belirsizliğin azaltılması üzerinde etkili olması girişimcilik özelliklerinden risk alma eğilimi ve belirsizliğe karşı tolerans özelliklerinin araştırma kapsamına alınmasında etkendir.

Risk, "zarara uğrama tehlikesi, riziko" olarak tanımlanmıştır (TDK, 2019). Risk alma eğilimi ise bireyin belirsiz bir durumda vereceği karar ve şans faktörünü dengelemesi anlamına gelmektedir (Koh, 1996: 15). Risk almak ve girişimcilik birbirleriyle özdeşleşmiş kavramlardır. Öyle ki birçok girişimcilik tanımında ve girişimcilik özellikleri üzerine yapılan çalışmalarda "risk alma" ifadesi kullanılmaktadır (Brenkert, 2009: 450; Lee ve Hsieh, 2010: 110; 1997: 10'dan aktaran Börü, 2006: 25; Küçükaltan, 2009: 24).

Belirsizlik "bir kavram, anlatım ve ölçümün anlamca kapalı ya da çokanlamlı olma durumu" olarak tanımlanmaktadır (Sencer, 1981). Belirsizlik toleransı ise karmaşık, yabancı veya uyuşmayan bir uyaran veya durum karşısında bireylerin algılama ve bilgiyi işleme şeklini ifade etmektedir. Bireyin belirsizliğe karşı toleransı düşük ise tahmin edilemeyen durumlarda stres yaşar ve hızlıca tepki verir. Belirsiz durumlardan kaçınmaya çalışır. Tam tersi bir durumda; yani bireyin belirsizliğe karşı yüksek toleransı varsa belirsiz uyaranlar karşısında olmaktan hoşnut olur. Zor ama ilginç olduğunu düşünür (Furnham ve Ribchester, 1995: 179). Girişimciler ise belirsizliği bir fırsat olarak görmektedir. Fırsatları yakalamak için ise muğlak durumlarda faaliyet göstermeyi, karışıklığı kullanarak kontrolü elde almayı tercih etmektedirler (İpçioğlu ve Taşer, 2009: 16). Bu yönleriyle girişimcilerin belirsizliğe karşı toleransı yüksek bireyler olduğu söylenebilir. Ayrıca bir iş kurmaktan daha belirsiz durumların oldukça az olduğu düşünüldüğünde belirsizliğe karşı yüksek tolerans; girişimciler için oldukça önemli bir özellik olarak kendini göstermektedir (Çetinkaya Bozkurt, 2011: 14). 


\section{Finansal Okuryazarlık ve Girişimcilik}

Girişimcilerin finansal okuryazarlık seviyesine dair çalışmalar alınyazında yok denecek kadar azdır. Oysa bireylerin hayatlarının bir parçası haline gelen finansal okuryazarlık ticari işlemlerle ve ekonomiyle daha fazla ilgilenen girişimciler için daha büyük anlam ifade etmektedir. Konuyla ilgili alanyazın incelendiğinde Kutukız ve Özden'in (2018) kadın girişimcilerin finansal okuryazarlık düzeyleri hakkında istatistiki bilgilere yer verdiği görülmektedir. Araştırma sonuçları göstermektedir ki; finansal gelişmelerin takibinde internet $(\% 29,6)$, gazete-dergi $(\% 25,9)$ ve televizyon $(\% 25,9)$ en fazla kullanılan kaynaklar olmuştur. Kadın girişimcilerin finansal bilgi düzeyinin düşük olduğu tespit edilen çalışmada; en fazla doğru yanıtın dört işlem sorusunda $(\% 85,1)$ verildiği görülmüştür. Son 1 yılda birikim yapan ve borçlanan kadın girişimcilerin araştırıldığı çalışmada oranlar sırasıyla \%55,5 ve \% 74 olarak bulunmuştur. Araştırmada finansal ihtiyacın en fazla bankalar $(\% 48,1)$ aracılığı ile giderildiği, kârlılığı en fazla etkileyen unsurun personel giderleri $(\% 35,1)$ olduğu, en büyük engelin de sermaye yetersizliği $(\% 51,8)$ olarak görüldüğü sonucuna ulaşılmıştır. Ayrıca, eğitim ve gelir düzeyinin finansal tutumu etkilediği tespit edilirken, yaşın anlamlı bir etkisi olmadığı görülmüştür.

Başka çalışmalarda finansal okuryazarlık seviyesinin girişimcilik niyeti ve girişimciliği cazip bulma ile ilişkilendirildiği görülmektedir. Finansal okuryazarlık ile girişimcilik niyeti ve girişimciliği cazip bulma arasındaki ilişki Seyrek ve Gül (2017) tarafından araştırılmış ve örneklem olarak farklı fakültelerde öğrenim gören lisans öğrencileri seçilmiştir. Araştırma sonucuna göre finansal okuryazarlık düzeyinin girişimciliği cazip bulma değişkenini pozitif ve anlamlı bir şekilde etkilediği saptanırken finansal okuryazarlığın girişimcilik niyeti üzerinde anlamlı bir etkisinin olmadığı görülmüştür. Sezici ve Çelikkol (2016) da finansal okuryazarlığı bağımlı değişken olarak ele almış ve girişimcilik niyeti üzerindeki etkisi ile algılanan sosyal desteğin bu etkideki rolünü incelemişlerdir. Çalışmada finansal okuryazarlık ile girişimcilik niyeti arasında pozitif yönlü bir ilişki tespit edilirken algılanan sosyal desteğin tam aracılık rolü saptanmıştır.

\section{Araştırmanın Amacı ve Metodolojisi}

Bu çalışmanın temel amacı Batı Akdeniz bölgesinde faaliyet gösteren girişimcilerin finansal okuryazarlık seviyesinin, girişimci özelliklerinden olan risk alma eğilimi ve belirsizliğe karşı tolerans değişkenleriyle ilişkisini ortaya çıkartmaktır. Bu temel amacın yanı sıra finansal okuryazarlık seviyesini oluşturan finansal bilgi, finansal tutum ve finansal davranış seviyeleri ile risk alma ve belirsizliğe karşı tolerans değişkenleri arasındaki ilişki de tartışılacaktır.

Konuyla ilgili alanyazında girişimcilerin sahip olduğu özelliklerle finansal okuryazarlık seviyesini ilişkilendiren çalışma yok denecek kadar azdır. Bu yönüyle çalışmanın ilgili literatüre önemli bir katkı sağlayacağı düşünülmektedir.

\subsection{Veri Toplama Aracı}

Bu araştırmada nicel araştırma yöntemlerinden biri olan anket tekniği kullanılmıştır. Çalışmada kullanılan soru formu üç bölümden oluşmaktadır. Birinci bölüm; girişimcilerin finansal okuryazarlık seviyesini ölçmek amacıyla OECD tarafından oluşturulan "2015 OECD/INFE Toolkit for Measuring Financial Literacy and Financial Inclusion" çalışmasından yararlanılmıştır. Bu kısımda bazı ifadelere yer verilmiş ve girişimcilerin ifadelere katılma dereceleri öğrenilmek istenmiştir. Bazı sorularda ise tamamen bilgi seviyesini ölçme amaçlanmıştır. Ölçme aracında finansal bilgi puanını belirlemek amacıyla katılımcılara; bölme (1 soru), paranın zaman değeri (1 soru), faiz (3 soru), risk ve getiri ilişkisi (1 soru), enflasyon (1 soru) ve finansal ürünlerin çeşitlendirilmesi (1 soru) konularında sorular yöneltilmiştir. Katılımcılar, soruları doğru yanıtlaması 
durumunda " 1 " puan almakta iken yanlış cevap " 0 " puan olarak değerlendirilmiştir. Puanların toplamı ise finansal bilgi skorunu oluşturmaktadır. Finansal tutumun ölçülmesinde ise katılımcıların para-birikim ilişkisine dair 3 soru bulunmaktadır. Verilen ifadelere 1 (tamamıyla katılıyorum) ila 5 (tamamıyla katılmıyorum) arasında yanıtlar veren katılımcıların finansal tutum puanı bu sorulara verilen puanların ortalaması alınarak saptanmaktadır. Finansal davranış seviyesinin ölçülmesinde aktif tasarruf (1 soru), satın alma süreci (1 soru), zamanında fatura ödeme (1 soru), finansal durumun takibi (1 soru), uzun dönem finansal hedefler (1 soru), finansal ürün seçimi ( 2 soru) ve geçimi sağlama ( 2 soru) konularında sorular bulunmaktadır. Bu kısımdaki sorular ve puanlandırma çeşitlenmektedir. İlk soruda tasarruf eden katılımcılara 1 puan verilirken, tasarruf etmeyen katılımcılar 0 puan almışlardır. 1 (her zaman yaptığınız) ila 5 (hiç yapmadığınız) arasında değişen bir skalaya göre değişiklik gösteren satın alma süreci, zamanında fatura ödeme, finansal durumun takibi, uzun dönem finansal hedefler hakkındaki sorularda 1 ve 2 seçeneğini işaretleyen katılımcılara 1 puan verilirken; 3, 4 ve 5 seçeneklerini işaretleyen katılımcılara 0 puan verilmiştir. Finansal ürün seçiminde bağımsız bilgi veya tavsiyeyi dikkate alan katılımcılara 2 puan, yanlı bilgi ile hareket eden katılımcılara 1 puan ve diğer koşullara 0 puan verilmiştir. Geçimini sağlayamayan ve bu sebeple krediye başvuran katılımcılara 0 puan verilmişken geçim problemi yaşamayan veya yaşasa bile kredi dışındaki seçenekleri kullanan girişimcilere 1 puan verilmiştir. Verilen puanların toplamı ise finansal davranış skorunu oluşturmaktadır. Finansal okuryazarlık puanı ise finansal bilgi, finansal tutum ve finansal davranış puanlarının toplanması ve 100 "lük sisteme dönüştürülmesi şeklinde hesaplanmıştır.

Soru formunun ikinci kısmında araştırmaya katılan girişimcilerin risk alma eğiliminin ve belirsizliğe karşı tolerans seviyesinin ölçülmesi amaçlanmıştır. Finansal okuryazarlık kavramının risk ve getiri üzerinde durması ve finansal belirsizliğin azaltılması üzerinde etkili olması bu iki boyutun seçilmesinde etkili olmuştur. Bu doğrultuda Koh'un (1996) geliştirdiği ve Bozkurt tarafından (2005) Türkçeye uyarlanan otuz altı maddelik ölçeğin risk alma eğilimi (7) ve belirsizliğe karşı tolerans (9) seviyelerini ölçen toplam 16 ifade araştırma kapsamında kullanılmıştır. Bu bölümde yer alan bütün ifadeler $5^{\prime}$ li Likert tipinde derecelendirilmiştir. Soru formunun son bölümünü oluşturan üçüncü kısımda ise, girişimcilerin demografik özellikleri ve sahip olduğu firmalar hakkında sorular bulunmaktadır.

\subsection{Araştırmanın Örneklemi}

Araştırmanın evrenini, Batı Akdeniz Bölgesi'nde başka bir deyişle Antalya, Burdur ve Isparta illerinde faaliyet gösteren ve ticaret odasına kayıtlı olan girişimciler oluşturmaktadır. Ticaret odalarından 2018 yılında alınan verilere göre Antalya'da 33.734, Burdur'da 2.759 ve Isparta'da 5.706 kayıtlı girişimci bulunmaktadır. Olasılıklı olmayan örneklem tekniklerinden kota örneklem yönteminin kullanıldığı araştırmada örneklem sayısı, üç şehirde bulunan girişimci sayılarının toplam girişimci sayısına bölünmesiyle bulunan oran doğrultusunda oluşturulmuştur. Anket sayısı şehirler için belirlenen sayıya ulaştığında diğer şehirlerde faaliyet gösteren girişimcilere yönelinmiştir. Bu yöntem sonunda Antalya'dan 267, Burdur'dan 23 ve Isparta'dan 44 olmak üzere toplam 334 anket elde edilmiştir. Oluşturulan soru formu katılımcılara yüz yüze görüşme, çevrimiçi anket formu ve e-posta aracılığı ile uygulanmıştır. Toplanan 10 ankette eksik verinin bulunduğu görülmüş ve araştırma kapsamından çıkarılmıştır. Analizler 324 anket dâhil edilerek gerçekleştirilmiştir. Evren sayısı 500.000 ve üzerinde iken seçilecek yeterli örneklem sayısı 381'dir (Gürbüz ve Şahin, 2016: 132). Bu durumda, araştırma kapsamında kullanılan örneklem büyüklüğünün yeterli olduğu düşünülmektedir. 
Tablo 1 örneklem hakkında bilgi vermektedir. Tablo 1'e göre örneklemde erkek sayısı kadın sayısından fazladır. 20-40 yaş aralığında bulunan girişimcilerin örneklemin yarısından fazlasını oluşturduğu görülmektedir. Katılımcıların neredeyse yarısı ortaöğretim mezunudur. Büyük bir kısmının faaliyet bölgesi yerel düzeydedir. Araştırmaya katılan girişimcilerin yaklaşık yarısı tek başına çalışmakta olup, \%90'ı ihracat yapmamaktadır. Ayrıca katılımcılar, girişimci olarak daha yeni deneyim kazanmaktadırlar. Tablo 1'e göre yaklaşık \%40'ının girişimci olarak deneyim süresi 1 yılın altındadır. Katılımcıların \%80'i 5.000 TL altında gelire sahiptir ve \%70'i hizmet sektöründe bulunmaktadır. Hali hazırda çalıştıkları işletmenin yaşı sorulduğunda ise firmaların yaklaşık \%50'sinin 5 yıldan az süredir faaliyet gösterdiği görülmektedir.

Tablo 1: Örneklemin Bazı Değişkenlere Göre Dağılımları

\begin{tabular}{|c|c|c|c|c|c|}
\hline Cinsiyet & Sıklık & Yüzde (\%) & İhracat Durumu & Sıklık & Yüzde (\%) \\
\hline Kadın & 119 & 36,7 & Evet & 33 & 10,2 \\
\hline Erkek & 205 & 63,3 & Hayır & 291 & 89,8 \\
\hline Yaş Grubu & Sıklık & Yüzde (\%) & $\begin{array}{l}\text { Girişimci olarak faaliyette } \\
\text { bulunulan yıl }\end{array}$ & Sıklık & Yüzde (\%) \\
\hline 20 yaş ve altı & 10 & 3,1 & 1 yıldan az & 132 & 40,7 \\
\hline $20-30$ & 111 & 34,3 & $1-3 \mathrm{yll}$ & 66 & 20,4 \\
\hline $31-40$ & 103 & 31,8 & $4-6$ yıl & 60 & 18,6 \\
\hline $41-50$ & 70 & 21,6 & $7-9 \mathrm{yıl}$ & 23 & 7,0 \\
\hline 50 yaş üstü & 30 & 9,2 & 10 yıl ve üzeri & 43 & 13,3 \\
\hline Eğitim Durumu & Sıklık & Yüzde (\%) & Gelir Durumu & Sıklık & Yüzde (\%) \\
\hline ilköğretim & 41 & 12,7 & $5.000 \mathrm{TL}$ altı & 250 & 77,2 \\
\hline Ortaöğretim & 155 & 47,8 & $5.000 \mathrm{TL}-10.000 \mathrm{TL}$ & 50 & 15,4 \\
\hline Üniversite & 114 & 35,2 & 10.001 TL $-20.000 \mathrm{TL}$ & 10 & 3,1 \\
\hline Lisansüstü & 14 & 4,3 & 20.000 TL üstü & 14 & 4,3 \\
\hline $\begin{array}{l}\text { Firma faaliyet böl- } \\
\text { gesi }\end{array}$ & Sıklık & Yüzde (\%) & Sektör & Sıklık & Yüzde (\%) \\
\hline Yerel & 243 & 75 & Hizmet & 224 & 69,1 \\
\hline Bölgesel & 34 & 10,5 & Üretim & 53 & 16,4 \\
\hline Ulusal & 20 & 6,2 & Ticari & 47 & 14,5 \\
\hline Uluslararası & 27 & 8,3 & & & \\
\hline Çalışan Sayısı & Sıklık & Yüzde (\%) & Firma Yaşı & Sıklık & Yüzde (\%) \\
\hline Sadece kendim & 139 & 42,9 & 1 yıldan az & 72 & 22,2 \\
\hline $1-10$ & 115 & 35,5 & $1-5$ yıl & 85 & 26,2 \\
\hline $11-50$ & 26 & 8,0 & $6-10 \mathrm{yll}$ & 58 & 17,9 \\
\hline $51-250$ & 20 & 6,2 & $11-15$ yıl & 28 & 8,6 \\
\hline \multirow[t]{5}{*}{251 ve üstü } & 24 & 7,4 & $16-20$ yıl & 19 & 5,8 \\
\hline & & & $21-25$ yıl & 12 & 3,7 \\
\hline & & & $26-30$ yıl & 8 & 2,5 \\
\hline & & & 31 yıl ve üzeri & 42 & 13,1 \\
\hline & & & Toplam & 324 & 100,0 \\
\hline
\end{tabular}




\subsection{Araştırmanın Modeli ve Hipotezleri}

Şekil 1. Araştırma Modeli

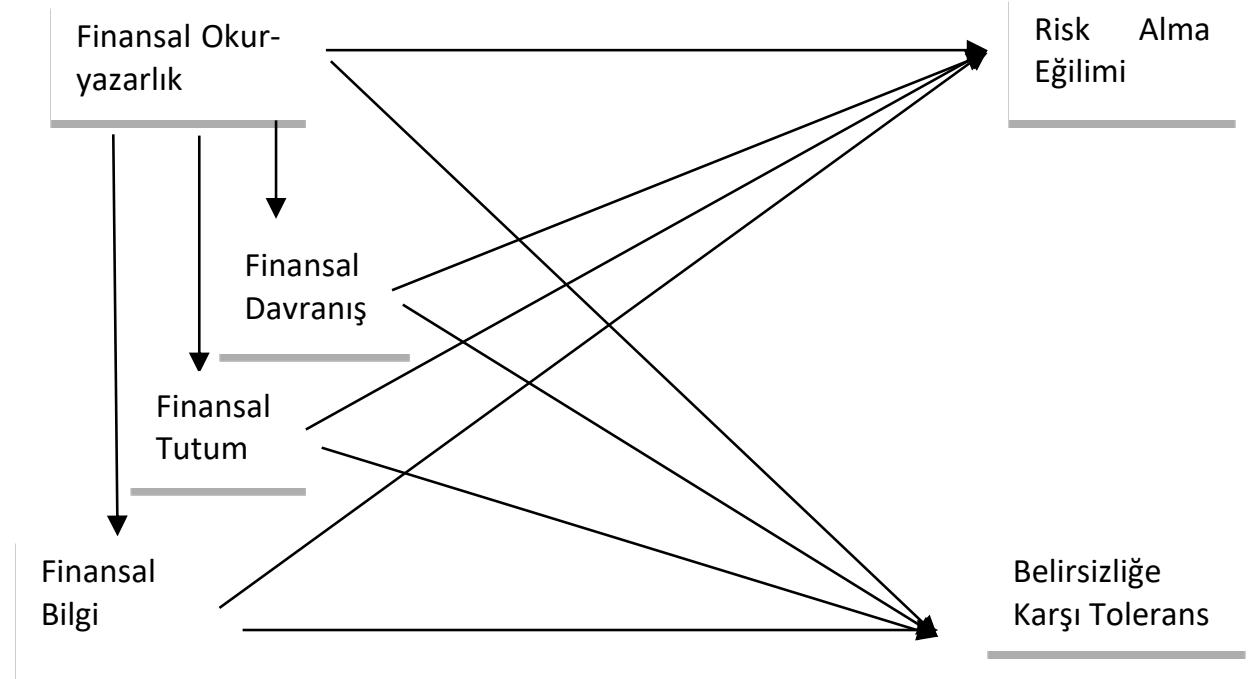

Şekil 1'deki araştırma modeline göre oluşturulan hipotezler şu şekildedir:

$\mathrm{H}_{1}$ :Girişimcilerin finansal bilgi seviyesi ile risk alma eğilimleri arasında istatistiksel olarak anlamlı bir ilişki vardır.

$\mathrm{H}_{2}$ : Girişimcilerin finansal tutum seviyesi ile risk alma eğilimleri arasında istatistiksel olarak anlamlı bir ilişki vardır.

$\mathrm{H}_{3}$ : Girişimcilerin finansal davranış seviyesi ile risk alma eğilimleri arasında istatistiksel olarak anlamlı bir ilişki vardır.

$\mathrm{H}_{4}$ : Girişimcilerin finansal okuryazarlık seviyesi ile risk alma eğilimleri arasında istatistiksel olarak anlamlı bir ilişki vardır.

$\mathrm{H}_{5}$ : Girişimcilerin finansal bilgi seviyesi ile belirsizliğe karşı tolerans seviyesi arasında istatistiksel olarak anlamlı bir ilişki vardır.

$\mathrm{H}_{6}$ : Girişimcilerin finansal tutum seviyesi ile belirsizliğe karşı tolerans seviyesi arasında istatistiksel olarak anlamlı bir ilişki vardır.

$\mathrm{H}_{7}$ : Girişimcilerin finansal davranış seviyesi ile belirsizliğe karşı tolerans seviyesi arasında istatistiksel olarak anlamlı bir ilişki vardır.

$\mathrm{H}_{8}$ : Girişimcilerin finansal okuryazarlık seviyesi ile belirsizliğe karşı tolerans seviyesi arasında istatistiksel olarak anlamlı bir ilişki vardır.

\subsection{Normallik Testi}

Çalışmada verilerin normal dağılımını incelemek amacıyla ilk olarak sosyal bilimlerde kullanılan Kolmogorov-Smirnov ve Shapiro Wilk testi kullanılmıştır. Bu testte normal dağılımın kabulü için $p$ değerinin 0,05'ten büyük olması gerekmektedir (Gürbüz ve Şahin, 2016: 218). Fakat 
yapılan analiz sonucunda verilerin normal dağılmadığı $(p<0,05)$ görülmüştür. Ardından ikinci yöntem olan Çarpıklık (Skewness) ve Basıklık (Kurtosis) katsayıları incelenmiştir. Verinin normalliğe yakın bir dağılıma sahip olabilmesi için bu değerlerin $+1,5$ ve $-1,5$ arasında olması gerekmektedir (Tabachnick ve Fidell, 2013). Araştırmaya ait çarpıklık ve basıklık değerleri Tablo 2'de verilmiş olup, finansal okuryazarlık, risk alma eğilimi ve belirsizliğe karşı tolerans verilerinin normal dağılım gösterdiği görülmektedir.

Tablo 2: Basıklık Çarpıklık Değerleri

\begin{tabular}{lcc}
\hline & Basıklık & Çarpıklık \\
\hline Finansal Okuryazarlık & $-0,466$ & $-0,304$ \\
\hline Risk Alma Eğilimi & $-0,641$ & $-0,051$ \\
\hline Belirsizliğe Karşı Tolerans & $-1,193$ & 0,479 \\
\hline
\end{tabular}

\subsection{Güvenilirlik Analizi}

Hipotez testlerine başlamadan önce ölçme araçlarının taşıması gereken bir özellik olan güvenilirlikleri incelenmiştir. Bu doğrultuda risk alma eğilimi ve belirsizliğe karşı tolerans değişkenlerinin ayrı ayrı Cronbach Alfa Güvenirlik Katsayıları dikkate alınmıştır. Cronbach alfa güvenirlik katsayısı için kabul edilebilir oran 0,70 ve üzeridir (Gürbüz ve Şahin, 2016: 325). Fakat yapılan analiz sonucunda cronbach alfa değerinin 0,70 'in altında kaldığı görülmüştür. Ölçeğin güvenilirliğini arttırmak amacıyla risk alma boyutundan iki, belirsizliğe karşı tolerans boyutundan bir ifade çıkarılmıştır. Yapılan değişiklikler sonucunda risk alma ve belirsizliğe karşı tolerans cronbach alfa değerlerinin istenilen düzeyde olduğu görülmüş olup, değerler Tablo 3'te verilmiştir.

Tablo 3: Cronbach Alfa Katsayıları

\begin{tabular}{llcc}
\hline Boyut & Ölçüm Aralığı & ifade Sayısı & Cronbach Alfa Katsayısı \\
\hline Risk Alma & 5'li Likert tipi Ölçek & 5 & 0,743 \\
\hline Belirsizliğe Karşı Tolerans & 5'li Likert tipi Ölçek & 8 & 0,717 \\
\hline
\end{tabular}

\subsection{Geçerlilik}

Araştırmada; daha önce oluşturulmuş ve literatüre kazandırılmış ölçüm araçlarının, farklı zamanlarda veya yerlerde toplanan veriler ile özgün yapısını koruyup korumadığını tespit etmek (Gürbüz ve Şahin, 2016: 334) amacıyla doğrulayıcı faktör analizi kullanılmıştır. İlk olarak değişkenlerin faktör analizine uygunluğu ve ifadelerin homojenliği test edilmiştir. Bu amaçla KaiserMeyer-Olkin (KMO) örneklem yeterliliği ölçütü ve Barlett Küresellik Testi kullanılmıştır. Bu analizde KMO değerinin en az 0,60 olması beklenirken, Barlett Küresellik Testi sonucunun anlamlı olması $(p<0,05)$ gerekmektedir (Gürbüz ve Şahin, 2016: 319).

Tablo 4: KMO ve Barlett Küresellik Testi

\begin{tabular}{lll}
\hline Test & Değer \\
\hline Kaiser-Meyer-Olkin (KMO) & & 0,885 \\
\hline Barlett Küresellik Testi & Yaklaşık Ki-Kare & 1649,347 \\
\hline & s.d. & 78 \\
\hline & P &, 000 \\
\hline
\end{tabular}

Tablo 4'te KMO değeri ve Barlett Küresellik Testi sonucu verilmiş olup, verilerin sayıltılara uygun olduğu görülmektedir. Başka bir deyişle örneklem faktör analizi için yeterli, değişkenler arası ilişkilerin oluşturduğu matris anlamlı ve veriler faktör analizi için uygundur. Ardından girişimcilik özellikleri alt boyutlarından olan risk alma eğilimi ve belirsizliğe karşı tolerans AMOS 21 
programı kullanılarak analiz edilmiştir. AMOS programında ölçeğin geçerli sayılabilmesi için bazı verilerin uyum indekslerine dair şartları sağlaması gerekmektedir (Yılmaz ve Varol, 2015: 34).

Yapılan analiz sonucunun bu uyum indekslerine uygun olmadığı görülmüş ve ölçüm aracı ile uyum göstermeyen maddeler tespit edilmiştir. Maddelerin çıkartılması işlemi sırasında her madde eksildiğinde faktör analizi tekrarlanmış ve uyum indeksleri gözlenmiştir. Bu doğrultuda da belirsizliğe karşı tolerans boyutunun üç maddesi ölçekten çıkartılmıştır. Araştırmada saptanan revize edilmiş uyum indeksleri Tablo 5 'te sunulmuştur.

Tablo 5: Model Uyum indeksleri

\begin{tabular}{lll}
\hline Uyum Ölçüsü & Araştırma Verileri & Uyum \\
\hline$X^{2} /$ sd & 2,222 & Kabul Edilebilir Uyum \\
\hline RMSEA & 0,062 & Kabul Edilebilir Uyum \\
\hline CFI & 0,97 & İyi Uyum \\
\hline GFI & 0,955 & İyi Uyum \\
\hline AGFI & 0,928 & İyi Uyum \\
\hline
\end{tabular}

Tablo 5 incelendiğinde uyum indekslerinin kabul edilebilir ve iyi uyum gösterdiği görülmektedir. Bu durumda elde edilen veriler ve maddelerin faktör yükleri modelin kabul edilebilir olduğunu göstermektedir. Açıklama oranları ve hata varyansları Şekil 2'de sunulmuştur.

\section{Şekil 1: Revize Edilmiş Faktör Modeli}

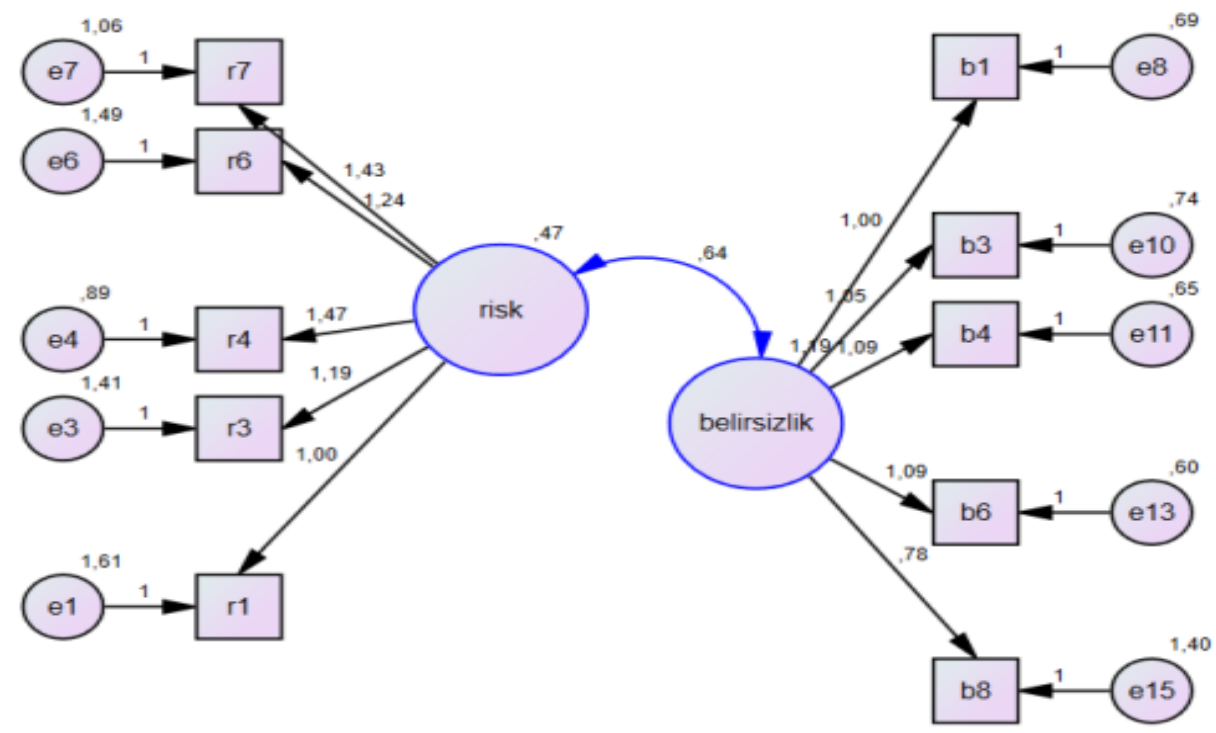

\subsection{Araştırmanın Bulguları}

Çalışmada finansal okuryazarlığın alt boyutları olan finansal bilgi seviyesi, finansal tutum seviyesi, finansal davranış seviyesi ve finansal okuryazarlık genel seviyesi ile kişilerin risk alma eği- 
limleri ve belirsizliğe karşı tolerans seviyeleri arasındaki ilişki en küçük kareler yöntemi yardımıyla analiz edilmiştir. En küçük kareler yöntemi hata terimlerinin karesini minimum yapma prensibi ile beta katsayısını tahmin etmektedir (Tarı, 2015: 67).

\subsubsection{Girişimcilerin Finansal Bilgi Seviyesi ile Risk Alma Eğilimleri Arasındaki ílişki}

Tablo 6'da bağımlı değişkenin risk alma seviyesi olduğu ve bağımsız değişkenin finansal bilgi seviyesi olduğu analiz sonuçları verilmiştir. Tablo 6 incelendiğinde T değeri olasılık değerinin 0.05 'ten küçük olması katsayının istatistiksel olarak anlamlı olduğunu göstermektedir. Bu durumda $\mathrm{H} 1$ hipotezi kabul edilmektedir. Yani girişimcilerin finansal bilgi seviyesi ile risk alma eğilimleri arasında istatistiksel olarak anlamlı bir ilişki vardır. Beta değeri katsayısının pozitif olması ilişkinin yönünün pozitif olduğunu gösterirken, standart beta değerinin 0,28 olması kişinin finansal bilgi seviyesindeki bir standart sapmalık artışın risk alma eğilimini 0,28 standart sapma artırdığını göstermektedir.

Tablo 6: Model sonuçları - Finansal Bilgi Seviyesi ile Risk Alma Eğilimi

\begin{tabular}{lcccc}
\hline & Beta Değeri & $\begin{array}{c}\text { Standart Beta De- } \\
\text { ğeri }\end{array}$ & T- Değeri & T Testi Olasılık Değeri \\
\hline Katsayılar & 0,184 & 0,28 & 5,249 & 0,000 \\
\hline
\end{tabular}

Tablo 7'de modelin bir bütün olarak anlamlılığı test eden F Testi sonuçları verilmiştir. Sonuçlar incelendiğinde F Testi olasılık değeri 0,05'ten küçük çıktığı için kurulan model bir bütün olarak anlamlıdır. En küçük kareler yönteminin temel varsayımları, kurulan modelde irdelenmiştir. Bunlardan birincisi hata terimlerinin normal dağılımıdır. Hata terimlerinin normal dağılımı basıklık çarpıklık değerleri yardımıyla incelenmiştir. Dağılımın normal kabul edilebilmesi için $+1,5$ ve $-1,5$ aralığında olması gerekmektedir (Tabachnick ve Fidell, 2013). Tablo 7'de tanı test sonuçları verilmiştir. Sonuçlar incelendiğinde çarpıklık ve basıklık değerlerinin bu aralıkta olduğu görülmektedir.

En küçük kareler yönteminin diğer bir varsayımı ise modelin hata terimleri arasında ilişki olmaması gerekliliğidir (Sevüktekin, 2007: 243). Bu soruna oto korelasyon sorunu denirken çaış̧mada oto korelasyon sorunu Durbin -Watson değeri yardımıyla incelenmiştir. Bu değerin ise 1,5-2,5 aralığında olması normal kabul edilirken (Kalaycı, 2005: 267) Tablo 7'de değerin 1,767 olduğu görülmektedir.

En küçük kareler yönteminin diğer varsayımı ise bağımsız değişkenler arasında ilişki olmamasıdır (Tarı, 2015: 66). Bu soruna çoklu doğrusal bağlantı sorunu denirken genellikle zaman serilerinde ve yatay kesit verilerinde görünür. Bu çalışmada kurulan sekiz modelde de tek bağımsız değişken kullanıldığı için bu varsayım test edilmemiştir.

Tablo 7: Tanı Test Sonuçları

\begin{tabular}{lcccccc}
\hline & $\begin{array}{c}\text { Durbin Wat- } \\
\text { son Değeri }\end{array}$ & $\begin{array}{c}\text { Düzeltilmiş } \\
\text { Re-Kare }\end{array}$ & $\begin{array}{c}\text { F- } \\
\text { Testi }\end{array}$ & $\begin{array}{c}\text { F Testi Ola- } \\
\text { sılık Değeri }\end{array}$ & $\begin{array}{c}\text { Artıkların Çar- } \\
\text { pıklık Değerleri }\end{array}$ & $\begin{array}{c}\text { Artıkların Ba- } \\
\text { sıklık Değeri }\end{array}$ \\
\hline $\begin{array}{l}\text { Finansal Bilgi Sevi- } \\
\text { yesi-Risk Alma Eği- }\end{array}$ & 1,767 & 0,076 & 27,554 &, 000 & $-0,507$ & 0,009 \\
limi
\end{tabular}

\subsubsection{Girişimcilerin Finansal Tutum Seviyesi ile Risk Alma Eğilimleri Arasındaki ílişki}

Tablo 8'de bağımlı değişkenin risk alma seviyesi olduğu ve bağımsız değişkenin finansal tutum seviyesi olduğu modelin tahmin sonuçları verilmiştir. Tablo 8 incelendiğinde T Testi olasılık değerinin 0,05 'ten küçük olması katsayının istatistiksel olarak anlamlı olduğunu gösterirken H2 
hipotezi kabul edilmektedir. Dolayısıyla girişimcilerin finansal tutum seviyesi ile risk alma eğilimleri arasında istatistiksel olarak anlamlı bir ilişki vardır. Beta değerinin katsayısının pozitif olması ilişkinin yönünü pozitif olduğunu gösterirken, standart beta değerinin 0,24 olması kişinin finansal tutum seviyesindeki bir standart sapmalık artışın risk alma eğilimini 0,24 standart sapma artırdığını göstermektedir.

Tablo 8: Model sonuçları (Finansal Tutum Seviyesi-Risk Alma Eğilimi)

\begin{tabular}{lcccc}
\hline & Beta Değeri & $\begin{array}{c}\text { Standart Beta De- } \\
\text { ǧeri }\end{array}$ & T- Değeri & T Testi Olasılık Değeri \\
\hline Katsayılar & 0,206 & 0,247 & 4,572 &, 000 \\
\hline
\end{tabular}

Hata terimlerinin normal dağılımı basıklık çarpıklık değerleri yardımıyla incelenmiş olup bu değerin +/-1,5 aralığında olması normal kabul edilmektedir (Tabachnick ve Fidell, 2013). Tablo 9 'da tanı test sonuçları verilmiştir. Sonuçlar incelendiğinde çarpıklık ve basıklık değerlerinin bu aralıkta olduğu gözükmektedir. Oto korelasyon sorunu çalışmada Durbin -Watson değeri yardımıyla incelenmiştir. Bu değerin ise 1,5-2,5 aralığında olması normal kabul edilirken Tablo 9'a göre modelin Durbin -Watson değeri 1,933'tür. Ayrıca F Testi olasılık değerinin 0,05'ten küçük çıkması modelin bir bütün olarak anlamlı çıktığını göstermektedir.

Tablo 9: Tanı Test Sonuçları

\begin{tabular}{|c|c|c|c|c|c|c|}
\hline & $\begin{array}{c}\text { Durbin Wat- } \\
\text { son Değeri }\end{array}$ & $\begin{array}{l}\text { Düzeltilmiş } \\
\text { Re-Kare }\end{array}$ & F- Testi & $\begin{array}{l}\text { F Testi Olası- } \\
\text { lık Değeri }\end{array}$ & $\begin{array}{c}\text { Artıkların Çar- } \\
\text { pıklık Değer- } \\
\text { leri }\end{array}$ & $\begin{array}{c}\text { Artıkların } \\
\text { Basıklık } \\
\text { Değeri }\end{array}$ \\
\hline $\begin{array}{l}\text { Finansal } \\
\text { Tutum Se- } \\
\text { vivesi-Risk }\end{array}$ & 1.933 & 0.058 & 20.900 & 000 & $-0,458$ & $-0,168$ \\
\hline $\begin{array}{l}\text { Alma Eği- } \\
\text { limi }\end{array}$ & & & & & & \\
\hline
\end{tabular}

\subsubsection{Girişimcilerin Finansal Davranış Seviyesi ile Risk Alma Eğilimleri Arasındaki iliş̧ki}

Tablo 10'da bağımlı değişkenin risk alma ve bağımsız değişkenin finansal davranış seviyesi olduğu modelin tahmin sonuçları verilmiştir. Tablo 10 incelendiğinde T Testi olasılık değerinin 0,05'ten büyük olması katsayının istatistiksel olarak anlamlı olmadığını gösterirken H3 hipotezi reddedilmektedir. Yani girişimcilerin finansal davranış seviyesi ile risk alma eğilimleri arasında istatistiksel olarak anlamlı bir ilişki yoktur.

Tablo 10: Model sonuçları (Finansal Davranış Seviyesi-Risk Alma Eğilimi)

\begin{tabular}{lcccc}
\hline & Beta Değeri & $\begin{array}{c}\text { Standart Beta De- } \\
\text { ğeri }\end{array}$ & T- Değeri & T Testi Olasılık Değeri \\
\hline Katsayılar & 0,026 & 0,051 &, 911 &, 363 \\
\hline
\end{tabular}

\subsubsection{Girişimcilerin Finansal Okuryazarlık Seviyesi ile Risk Alma Eğilimleri Arasındaki}

ilişki

Tablo 11'de bağımlı değişkenin risk alma ve bağımsız değişkenin finansal okuryazarlık seviyesi olduğu modelin tahmin sonuçları verilmiştir. Tablo 11 incelendiğinde T Testi olasılık değerinin 0,05'ten küçük olması katsayının istatistiksel olarak anlamlı olduğunu gösterirken $\mathrm{H} 4$ hipotezi kabul edilmektedir. Dolayısıyla girişimcilerin finansal okuryazarlık seviyesi ile risk alma eğilimleri arasında istatistiksel olarak anlamlı bir ilişki vardır. Beta değeri katsayısının pozitif olması 
ilişkinin yönünü pozitif olduğunu gösterirken, standart beta değerinin 0,27 olması kişinin finansal okuryazarlık seviyesindeki bir standart sapmalık artışın risk alma eğilimini 0,27 standart sapma artırdığını göstermektedir.

Tablo 11: Model sonuçları (Finansal Okur Yazarlık -Risk Alma Eğilimi)

\begin{tabular}{lcccc}
\hline & Beta Değeri & $\begin{array}{c}\text { Standart Beta De- } \\
\text { ǧeri }\end{array}$ & T- Değeri & T Testi Olasılık Değeri \\
\hline Katsayılar & 0,020 & 0,27 & 5,029 &, 000 \\
\hline
\end{tabular}

Hata terimlerinin normal dağılımı, basıklık çarpıklık değerleri yardımıyla incelenmiş olup; bu değerin +/-1,5 aralığında olması normal kabul edilmektedir (Tabachnick ve Fidell, 2013). Tablo 12 'de tanı test sonuçları verilmiştir. Sonuçlar incelendiğinde çarpıklık ve basıklık değerlerinin bu aralıkta olduğu gözükmektedir. Oto korelasyon sorunu çalışmada Durbin-Watson değeri yardımıyla incelenmiştir. Bu değerin ise 1,5-2,5 aralığında olması normal kabul edilirken Tablo 12'de değerin 1,905 olduğu görünmektedir. Ayrıca $F$ Testi olasılık değerinin 0,05'ten küçük çıkması modelin bir bütün olarak anlamlı çıktığını göstermektedir.

Tablo 12: Tanı Test Sonuçları

\begin{tabular}{lcccccc}
\hline & $\begin{array}{c}\text { Durbin } \\
\text { Watson } \\
\text { Değeri }\end{array}$ & $\begin{array}{c}\text { Düzeltilmiş } \\
\text { Re-Kare }\end{array}$ & F- Testi & $\begin{array}{c}\text { F Testi Olası- } \\
\text { lık Değeri }\end{array}$ & $\begin{array}{c}\text { Artıkların Çar- } \\
\text { pıklık Değer- } \\
\text { leri }\end{array}$ & $\begin{array}{c}\text { Artıkların } \\
\text { Basıklık De- } \\
\text { ǧeri }\end{array}$ \\
\hline $\begin{array}{l}\text { Finansal } \\
\text { Okur Yazarlık }\end{array}$ & 1,905 & 0,070 & 25,290 &, 000 & $-0,427$ & $-0,183$ \\
- -Risk Alma \\
Eğilimi
\end{tabular}

\subsubsection{Girişimcilerin Finansal Bilgi Seviyesi ile Belirsizliğe Karşı Tolerans Arasındaki İlişki}

Tablo 13'te bağımlı değişkenin belirsizliğe karşı tolerans ve bağımsız değişkenin finansal bilgi seviyesi olduğu modelin tahmin sonuçları verilmiştir. Tablo 13 incelendiğinde T Testi olasılık değerinin 0,05'ten küçük olması katsayının istatistiksel olarak anlamlı olduğunu gösterirken H5 hipotezi kabul edilmektedir. Dolayısıyla girişimcilerin finansal bilgi seviyesi ile belirsizliğe karşı tolerans seviyesi arasında istatistiksel olarak anlamlı bir ilişki vardır. Beta değerinin katsayısının pozitif olması ilişkinin yönünün pozitif olduğunu, standart beta değerinin 0,34 olması kişinin finansal bilgi seviyesindeki bir standart sapmalık artışın belirsizliğe karşı toleransı 0,34 standart sapma artırdığını göstermektedir.

Tablo 13: Model sonuçları (Finansal Bilgi Seviyesi -Belirsizliğe Karşı Tolerans Seviyesi)

\begin{tabular}{lcccc}
\hline & Beta Değeri & $\begin{array}{c}\text { Standart Beta De- } \\
\text { ğeri }\end{array}$ & T- Değeri & \multicolumn{2}{c}{$\begin{array}{c}\text { T Testi Olasılık De- } \\
\text { ğeri }\end{array}$} \\
\hline Katsayılar & 0,265 & 0,347 & 9,076 &, 000 \\
\hline
\end{tabular}

Tablo 14'te modelin tanı test sonuçları verilmiştir. Hata terimlerinin normal dağılımı basıklık çarpıklık değerleri yardımıyla incelenmiş olup bu değerin $+/-1,5$ aralığında olması normal kabul edilmektedir (Tabachnick ve Fidell, 2013). Tablo 14'te basıklık ve çarpıklık sonuçları verilmiştir. Sonuçlar incelendiğinde çarpıklık ve basıklık değerlerinin bu aralıkta olduğu görünmektedir. Oto korelasyon sorunu çalışmada Durbin-Watson değeri yardımıyla incelenmiştir. Bu değerin ise 1,5-2,5 aralığında olması normal kabul edilirken Tablo 14'te Durbin -Watson değeri 1,765'tir. Bu değer oto korelasyon sorunu olmadığını ifade etmektedir. Ayrıca F Testi olasılık değerinin 0,05’ten küçük çıkması modelin bir bütün olarak anlamlı çıktığını göstermektedir. 
Eskişehir Osmangazi Üniversitesi ïBß Dergisi

Tablo 14: Tanı Test Sonuçları

\begin{tabular}{lcccccc}
\hline & $\begin{array}{c}\text { Durbin Wat- } \\
\text { son Değeri }\end{array}$ & $\begin{array}{c}\text { Düzeltilmiş Re- } \\
\text { Kare }\end{array}$ & F- Testi & $\begin{array}{c}\text { F Testi Olası- } \\
\text { lık Değeri }\end{array}$ & $\begin{array}{c}\text { Artıkların Çar- } \\
\text { pıklık Değer- } \\
\text { leri }\end{array}$ & $\begin{array}{c}\text { Artıkların } \\
\text { Basıklık } \\
\text { Değeri }\end{array}$ \\
\hline $\begin{array}{l}\text { Finansal Bilgi } \\
\text { Seviyesi -Belir- } \\
\text { sizliğe Karşı To- } \\
\text { lerans Seviyesi }\end{array}$ & 1,765 &, 118 & 44,192 &, 000 & $-1,011$ &, 583 \\
\hline
\end{tabular}

\subsubsection{Girişimcilerin Finansal Tutum Seviyesi ile Belirsizliğe Karşı Tolerans Arasındaki İlişki}

Tablo 15'te bağımlı değişkenin belirsizliğe karşı tolerans ve bağımsız değişkenin finansal tutum seviyesi olduğu modelin tahmin sonuçları verilmiştir. Tablo 15 incelendiğinde T Testi olasılık değerinin 0,05'ten küçük olması katsayının istatistiksel olarak anlamlı olduğunu gösterirken H6 hipotezi kabul edilmektedir. Yani, girişimcilerin finansal tutum seviyesi ile belirsizliğe karşı tolerans arasında istatistiksel olarak anlamlı bir ilişki vardır. Beta değerinin katsayısının pozitif olması ilişkinin yönünün pozitif olduğunu ifade ederken, standart beta değerinin 0,20 olması kişinin finansal tutum seviyesindeki bir standart sapmalık artışın belirsizliğe karşı toleransı 0,20 standart sapma artırdığını göstermektedir.

Tablo 15: Model sonuçları (Finansal Tutum Seviyesi-Belirsizliğe Karşı Tolerans Seviyesi)

\begin{tabular}{lcccc}
\hline & Beta Değeri & $\begin{array}{c}\text { Standart Beta De- } \\
\text { ğeri }\end{array}$ & T- Değeri & $\begin{array}{c}\text { T Testi Olasılık De- } \\
\text { geri }\end{array}$ \\
\hline Katsayılar & 0,195 & 0,201 & 3,684 &, 000 \\
\hline
\end{tabular}

Tablo 16 ' da hata terimlerinin normal dağılımı için basıklık, çarpıklık sonuçları incelendiğinde değerlerin $+1,5$ ve $-1,5$ aralığında olup, normal dağıldığı kabul edilmektedir. Oto korelasyon sorunu çalışmada Durbin-Watson değeri yardımıyla incelenmiştir. Bu değerin ise 1,5-2,5 aralığında olması normal kabul edilirken Tablo 16 'da değerin 1,926 olduğu gözükmektedir. Bu değer oto korelasyon sorunu olmadığını ifade etmektedir. Ayrıca F Testi olasılık değerinin 0,05 'ten küçük çıkması modelin bir bütün olarak anlamlı olduğunu ispatlamaktadır.

Tablo 16: Tanı Test Sonuçları

\begin{tabular}{|c|c|c|c|c|c|c|}
\hline & $\begin{array}{c}\text { Durbin } \\
\text { Watson } \\
\text { Değeri }\end{array}$ & $\begin{array}{l}\text { Düzeltilmiş } \\
\text { Re-Kare }\end{array}$ & F- Testi & $\begin{array}{l}\text { F Testi Olası- } \\
\text { lık Değeri }\end{array}$ & $\begin{array}{c}\text { Artıkların Çar- } \\
\text { pıklık Değer- } \\
\text { leri }\end{array}$ & $\begin{array}{c}\text { Artıkların } \\
\text { Basıklık De- } \\
\text { ğeri }\end{array}$ \\
\hline $\begin{array}{l}\text { Finansal Tutum } \\
\text { Seviyesi-Belirsiz- }\end{array}$ & & & & & & \\
\hline $\begin{array}{l}\text { liğe Karşı Tole- } \\
\text { rans Seviyesi }\end{array}$ & 1,926 & 0,037 & 13,574 & ,000 & $-1,030$ & 0,415 \\
\hline
\end{tabular}

\subsubsection{Girişimcilerin Finansal Davranış Seviyesi ile Belirsizliğe Karşı Tolerans Arasındaki ilişki}

Tablo 17'de bağımlı değişkenin belirsizliğe karşı tolerans seviyesi ve bağımsız değişkenin finansal tutum seviyesi olduğu modelin tahmin sonuçları verilmiştir. Tablo 17 incelendiğinde $T$ Testi olasılık değerinin 0,05 'ten büyük olduğu ve katsayının istatistiksel olarak anlamlı olmadığı görülmektedir. $\mathrm{H} 7$ hipotezi reddedilmektedir. Yani girişimcilerin finansal davranış seviyesi ile belirsizliğe karşı tolerans arasında istatistiksel olarak anlamlı bir ilişki yoktur. 
Tablo 17: Model sonuçları (Finansal Davranış Seviyesi -Belirsizliğe Karşı Tolerans Seviyesi)

\begin{tabular}{lcccc}
\hline & Beta Değeri & $\begin{array}{c}\text { Standart Beta De- } \\
\text { ğeri }\end{array}$ & T- Değeri & $\begin{array}{c}\text { T Testi Olasilık De- } \\
\text { ğeri }\end{array}$ \\
\hline Katsayılar & 0,011 & 0,019 & 0,340 &, 734 \\
\hline
\end{tabular}

\subsubsection{Girişimcilerin Finansal Okuryazarlık Seviyesi ile Belirsizliğe Karşı Tolerans Arasındaki iliş̧ki}

Tablo $18^{\prime}$ de bağımlı değişkenin belirsizliğe karşı tolerans ve bağımsız değişkenin finansal okuryazarlık seviyesi olduğu modelin tahmin sonuçları verilmiştir. Tablo incelendiğinde T değeri olasılık değerinin 0,05'ten küçük olması katsayının istatistiksel olarak anlamlı olduğunu gösterirken $\mathrm{H} 8$ hipotezi kabul edilmektedir. Yani, girişimcilerin finansal okuryazarlık seviyesi ile belirsizliğe karşı tolerans arasında istatistiksel olarak anlamlı bir ilişki vardır. Beta değeri katsayısının pozitif olması ilişkinin yönünün pozitif olduğunu, standart beta değerinin 0,26 olması kişinin finansal okuryazarlık seviyesindeki bir standart sapmalık artışın belirsizliğe karşı toleransı 0,26 standart sapma artırdığını göstermektedir.

Tablo 18: Model sonuçları (Finansal Okur Yazarlık - Belirsizliğe Karşı Tolerans Seviyesi)

\begin{tabular}{|c|c|c|c|c|}
\hline & Beta Değeri & $\begin{array}{c}\text { Standart Beta De- } \\
\text { ğeri }\end{array}$ & T- Değeri & $\begin{array}{c}\text { T Testi Olasılık De- } \\
\text { ğeri }\end{array}$ \\
\hline Katsayılar & 0,023 & 0,265 & 4,935 &, 000 \\
\hline
\end{tabular}

Tablo 19'da modelin tanı test sonuçları verilmiştir. Hata terimlerinin normal dağılımı basıklık çarpıklık değerleri yardımıyla incelenmiş olup bu değerin $+/-1,5$ aralığında olması normal kabul edilmektedir (Tabachnick ve Fidell, 2013). Tablo 19'da basıklık, çarpıklık sonuçları verilmiştir. Sonuçlar incelendiğinde çarpıklık ve basıklık değerlerinin bu aralıkta olduğu gözükmektedir. Oto korelasyon sorunu çalışmada Durbin-Watson değeri yardımıyla incelenmiştir. Bu değerin ise 1,5-2,5 aralığında olması normal kabul edilirken Tablo 19'da değerin 1,892 olduğu gösterilmiştir. Bu değer oto korelasyon sorunu olmadığını göstermektedir.

Tablo 19: Tanı Test Sonuçları

\begin{tabular}{lcccccc}
\hline & $\begin{array}{c}\text { Durbin } \\
\text { Watson } \\
\text { Değeri }\end{array}$ & $\begin{array}{c}\text { Düzeltilmiş } \\
\text { Re-Kare }\end{array}$ & F- Testi & $\begin{array}{c}\text { F Testi Olası- } \\
\text { lık Değeri }\end{array}$ & $\begin{array}{c}\text { Artıkların Çar- } \\
\text { pıklık Değer- } \\
\text { leri }\end{array}$ & $\begin{array}{c}\text { Artıkların } \\
\text { Basıklık } \\
\text { Değeri }\end{array}$ \\
\hline $\begin{array}{l}\text { Finansal Okur Ya- } \\
\text { zarlık -Belirsizliğe } \\
\text { Karşı Tolerans Se- } \\
\text { viyesi }\end{array}$ & 1,892 & 0,067 & 24,339 & \multirow{2}{*}{000} & $-0,976$ & 0,316 \\
\hline
\end{tabular}

\section{Sonuç ve Öneriler}

Ülkeler arasında emeğin ve sermayenin serbestçe dolaşabilme sürecine küreselleşme denmektedir. Küreselleşmeyle birlikte bölgesel başlayan bir ekonomik kriz uluslararası bir krize dönüşebilmektedir. Ulusal ekonomilerde istikrar sürerken, ülkeler kendilerinden kaynaklanmayan sebeplerden dolayı krize girebilmektedirler. Dünya ekonomisinin son yüzyılı incelendiğinde 1929 ekonomik buhranıyla başlayan dünya savaşlarından sonra devam eden 1970'li yıllarda petrol krizleri ile tekrar başlayan ve 2008 ABD kaynaklı mortgage finansal kriziyle zirveye ulaşan birçok küresel ekonomik kriz yaşanmıştır. Bu krizler en çok düşük gelir grubundaki insanları et- 
kilerken makroekonomik dengelerin bozulmasına ve özellikle az gelişmiş ve gelişmekte olan ülkelerde işsizliğin artmasına neden olmuştur. Bugün dünyada yaklaşık bir milyar kişinin günlük bir doların altında gelire sahip olduğu tahmin edilmektedir.

Kişilerin kullanılabilir kişisel gelirindeki azalışlar, mevcut bütçeleri etkin ve verimli bir biçimde kullanmasını zorunlu hale getirirken gerek mevcut ekonomik koşulların doğru analizi gerekse geleceğe dair bir provizyon oluşumu anlamında finansal okuryazarlık önemli ve popüler bir kavram haline gelmiştir. Günümüz zorlu ve karmaşık ekonomik koşullarında varlığını sağlıklı bir biçimde sürdürmek isteyen bireylerin belirli bir seviyede finansal konularda farkındalığa sahip olması gerekmektedir. Dolayısıyla bir iş fikri ile yola çıkan, bunu hayata geçiren ve devamlıIığı için uğraş veren girişimciler için finansal terimler hakkında bilgi sahibi olma, basit hesaplamaları yapabilme, ekonomik değişkenleri yorumlayabilme, bilgileri tutuma ve ardından davranışa geçirebilme önem arz etmektedir.

Çalışmada Batı Akdeniz bölgesinde faaliyet gösteren girişimcilerin finansal okuryazarlık seviyesi ile finansal okuryazarlık seviyesini oluşturan finansal bilgi, finansal tutum ve finansal davranış seviyelerinin girişimci özelliklerinden olan risk alma eğilimi ve belirsizliğe karşı tolerans değişkenleriyle ilişkisi araştırılmıştır. Analiz sonucuna göre değişkenlerin aynı yönde hareket ettiği görülmektedir. Finansal okuryazarlık seviyesinin girişimcilik özelliklerinden olan risk alma eğilimi ve belirsizliğe karşı tolerans değişkenlerini pozitif yönde etkilemesi dolayısıyla finansal okuryazarlık seviyesinin girişimci sayısının artmasında etkili olabileceği söylenebilir. Bu sonuç Seyrek ve Gül'ün (2017:113-114) finansal okuryazarlık seviyesinin girişimciliği cazip bulmaya olan etkisini gösteren çalışmasıyla da paralellik göstermektedir.

Çalışma kapsamında finansal okuryazarlık genel seviyesinin, kişilerin risk alma eğilimini, belirsizliğe karşı tolerans seviyesinden daha fazla etkilediği de saptamıştır. Finansal okuryazarlık seviyesindeki artış kişilerin alan hâkimiyetini artırmakta ve iktisadi verileri daha iyi analiz edip geleceğe ilişkin doğru tahminler yapmasına neden olarak, bireylerin daha çok ve daha kolay risk almasına sebep olmaktadır. Ayrıca finansal okuryazarlık seviyesindeki artış, kişilerde bilgi ve başarı kaynaklı özgüvenin artışına neden olduğu için ekonomide beklenmeyen bir durum gerçekleştiğinde hemen geri çekilmek ya da vazgeçmek yerine riski fırsata çevirme eğilimini artırmaktadır.

Araştırmada finansal bilgi seviyesindeki ve finansal tutum seviyesindeki bir artışın da risk alma eğilimini ve belirsizliğe karşı toleransı artırırken finansal davranış seviyesinin bu değişkenler üzerinde anlamlı bir etkisi olmadığı saptanmıştır. Fakat beta değerleri incelendiğinde finansal davranış seviyesi değişkenleri anlamlı bir şekilde etkilemese dahi finansal davranış, risk alma eğilimi ve belirsizliğe karşı toleransla birlikte hareket ettiği görülmektedir.

Sonuç olarak finansal okuryazarlık seviyesinin risk alma eğiliminde ve belirsizliğe karşı toleransta anlamlı bir artışa neden olması; girişimcilik faaliyetlerinin sayısının ve başarısının üzerinde de etkili olacağını düşündürtmektedir. Dolayısıyla girişimlerin sayısının arttırılması amacıyla uygulanan politikalarda finansal okuryazarlık konusunun da dikkate alınması önerilmektedir. Ayrıca bu çalışmada iki boyutu kullanılan girişimcilik kişilik özelliklerinin, tüm boyutları dikkate alınarak araştırmacılar tarafından daha detaylı incelenebilir. Hatta çalışma tüm Türkiye'yi kapsayacak şekilde uygulanabilir. 


\section{Kaynaklar}

Abreu, Margarida; Mendes, Victor (2010), "Financial Literacy and Portfolio Diversificetion”, Quantitative Science, Vol. 10 NO.5,: 515-528.

Alkaya, Aylin; Yağlı, İbrahim (2015), “Finansal Okuryazarlık - Finansal Bilgi, Davranış ve Tutum: Nevşehir Hacı Bektaş Veli Üniversitesi İibf Öğrencileri Üzerine Bir Uygulama”, Uluslararası Sosyal Araştırmalar Dergisi, C.8 S.40: 585- 599.

Ansong, Abraham; Gyensare, Michael Asiedu (2012), “Determinant of University Working Students' financial Literacy at the University of Cape Coast, Ghana", International Journal of Business and Management, C.7 S.9: 126-133.

Atkinson, Adele; Messy, Flore Anne (2012), “Measuring Financial Literacy: Results of OECD/International Network on Financial Education (INFE) Pilot Study", OECD Working Papers on Finance, Insurance and Private Pensions, No.15.

Beal, Diana; Delpachitra, Sarath (2003), "Financial Literacy Among Australian University Students", Economic Papers, C. 22 S. 1: 65-78.

Bianco, Candy. A.; Bosco, Susan. M. (2000), “Financial Literacy: What are Business Schools Teaching?”, Journal of Global Business Management, vol. 7, No. 1.

BOZKURT, Öznur (2005). Girişimci Kişilik Özellikleri ve Sakarya Üniversitesi Örneği. Sakarya Üniversitesi Yayınlanmamış Yüksek Lisans Tezi, Sakarya.

Bönte, Werner; Filipiak, Ute (2012), “Financial Literacy,linformation Flows and Cate Affiliation: Empirical Evidencefrom India", Journal of Banking and Finance, 36: 3399- 3414.

Börü, Deniz (2006), Girişimcilik Eğilimi Marmara Üniversitesi İ̧̧letme Bölümü Öğrencileri Üzerine Bir Araştırma.. İstanbul: Marmara Üniversitesi. Yayın No.733

Brenkert, George (2009). "Innovation, Rule Breaking and The Ethics of Entrepreneurship", Journal of Business Venturing, C.24 S.5: 448-464.

Brown, Reva Berman; Saunders, Mark N; Beresford, Richard. (2006), "You owe it to yourself: The financially literate manager", Accounting Forum, C.30 S.2: $179-191$.

Chen, Haiyang; Volpe, Ronald P. (1998). "An Analysis of Personal Financial Literacy Among College Students”, Financial Services Review, C.7 S.2: 107-128.

Chinen, Kenichiro; Endo, Hideki (2012), “Effects of Attitude and Background on Students' Personal Financial Ability: A United States Survey", Internetional Journal of Management .C. 29 S.2: $778-791$.

Coulter, Mary; Robbins, P. Stephen. (2003), Management, 7.baskı, New Jersey: Prentice Hall.

Cude, Brenda. J.; Lawrance, Frances C.; Lyons, Angela. C.; Metzger, Kaci; LeJeune, Emily.; Marks, Loren.; Machtmes, Krisanna. (2006)," Collage Sudents and financial literacy: What they know and what we need to learn", Eastern Family Economics and Resource Management Association, (102 - 109).

Çelik, Adnan; Akgemci, Tahir; Şimşek, M. Şerif (2013). Girişimcilik ve Küçük Iş̧letme Yönetimi, Ankara: Gazi Kitapevi.

Çetinkaya Bozkurt, Özlem (2011). Dünyada ve Türkiye’de Girişimcilik Eğitimi: Başarılı Girişimciler ve Öğretim Üyelerinden Öneriler, Ankara: Detay Yayıncılık.

Dağdelen, Tarık (2017). Finansal Okuryazarlık Düzeyinin Belirlenmesi ve Aydın İlindeki Serbest Muhasebeci Mali Müşavirler Üzerine Bir Uygulama, Adnan Menderes Üniversitesi Yayınlanmamış Yüksek Lisans Tezi, Aydın

Disney, Richard; Gathergood, John (2013), "Financial Literacy And Consumer Credit Portfolios", Journal of Banking \& Finance, 37: 2246-2254.

Er, Fikret; Temizel, Fatih; Özdemir, Ali; Sönmez, Harun (2014). “Lisans Eğitim Programlarının Finansal Okuryazarlık Düzeyine Etkisinin Araştırılması: Türkiye Örneği”, Anadolu Üniversitesi Sosyal Bilimler Dergisi, C.14 S.4, (113-126).

Fiş, Ahmet Murat; Wasti, S. Arzu (2009). “Örgüt Kültürü ve Girişimcilik Yönelimi İlişkisi”. ODTÜ Gelişme Dergisi, C.35 Özel Sayı:127-164.

Foder (2019). “Finansal okuryazarlık ve erişim”, https://www.fo-der.org/, (Erişim: 2018)

Furnham, Adrian; Ribchester, Tracy (1995), "Tolerance of Ambiguity: A Review of the Concept, its Measurement and Applications", Current psychology, C.14 S.3: 179-199.

Gürbüz, Sait; Şahin, Faruk (2016), Sosyal Bilimlerde Araştırma Yöntemleri: Felsefe - Yöntem- Analiz, Ankara: Seçkin Yayınları.

Hardy, Ken (1999). "What Do Entrepreneurs Contribute?", Ivy Business Journal, C.64 S.2: 48-65. 


\section{Eskişehir Osmangazi Üniversitesi IïB Dergisi}

İpçioğlu, İsa; Taşer, Atıl (2009). “iş̧letme Bölümlerinde Verilen Eğitimin Girişimci Adayı Öğrenciler Üzerindeki Etkileri”. Süleyman Demirel Üniversitesi Sosyal Bilimler Enstitüsü Dergisi, 10: 13-25.

İrmiş, Ayşe; Durak, İbrahim; Özdemir, Lütfiye (2010). Girişimcilik Kültürü: Anadolu Girişimciliğinden Örnekler, Bursa: Ekin Basın Yayın Dağıtım.

Kalaycı, Şeref (2005), SPSS Uygulamalı Çok Değişkenli Istatistik Teknikleri, 1.Baskı, Ankara: Asil Yayın Dağıtım.

Koh, Hian Chye (1996), "Testing hypotheses of entrepreneurial characteristics: A study of Hong Kong MBA students", Journal of Managerial Psychology, C. 11 S. 3: 12-25, https://doi.org/10.1108/02683949610113566

Kutukız, Doğan; Özden, Ceren (2018). "Kadın girişimciliği ve finansal okuryazarlığın kadın girişimciler üzerindeki etkisi”, Uluslararası Toplum Araştırmaları Dergisi, C. 8 S.8: 349-365

Küçükaltan, Derman (2009), "Genel Bir Yaklaşımla Girişimcilik”, Girişimcilik ve Kalkınma Dergisi. C.4 S.1: 21-28.

Lee, Jia-Sheng; Hsieh, Chia-Jung (2010), “A Research in Relating Entrereneurship, Marketing Capability, Innovative Capability and Sustained Competitive Advantage", Journal of Business-Ekonomics Research, C.8 S.9: 109- 119.

Louw, Jurgens; Fouche, Jaco; Oberholzer, Merwe (2013),"Financial Literacy Needs Of South African Third-Year University Students", International Business \& Economics Research Journal, C. 12, S. 4, :439-450.

Mc Clelland, David C. (1987). "Characteristics of Successful Entrepreneurs", The Journal Of Creative Behavior, C.21 S.3, (219-233)

Noctor, M.; Stoney, S.; Stradling, R. (1992), Financial Literacy: A Discussion Of Concepts And Competences Of Financial Literacy And Opportunities for its Introduction into Young People's Learning. Londra : National Foundation for Educational Research.

OECD (2017), "G20/OECD INFE report on adult financial literacy in G20 countries", http://www.oecd.org/daf/fin/financial-education/G20-OECD-INFE-report-adult-financial-literacy-in-G20-countries.pdf (Erişim:2018)

OECD INFE (2011), Measuring Financial Literacy: Core Questionnaire in Measuring Financial Literacy: Questionnaire and Guidance Notes for conducting an Internationally Comparable Survey of Financial literacy. Paris: OECD.

Özgüner, Mert. (2015), “Girişimcilik Tipleri ve Kişilik Tipleri İlişkisi Üzerine Bir İnceleme”, Route Educational and Social Science Journal, C.2 S.1: 148-160.

Öztürk, Elvan. (2014). Finansal Okuryazarlık ve Para Yönetimi: Süleyman Demirel Üniversitesi Akademik Personel Üzerine Bir Uygulama, Süleyman Demirel Üniversitesi Sosyal Bilimler Enstitüsü Yayınlanmamış Yüksek Lisans Tezi, Isparta

Sencer, Muzaffer. (1981). Yöntembilim Terimleri Sözlüğü, Ankara: Türk Dil Kurumu Yayınları.

Sevüktekin, Mustafa. (2007). Ekonometrik Zaman Serileri Analizi, Ankara: Nobel Yayınevi.

Seyrek, İbrahim H.; Gül, Meryem (2017), "Finansal Okuryazarlık Ve Girişimcilik Niyeti: Üniversite Öğrencileri Üzerine Bir Araştırma”, Yönetim ve Ekonomi Araştırmaları Dergisi. C.15 S.2: 103-118.

Sezici, Emre; Çelikkol, Mediha Mine (2016), "Girişimcilik Tutumu ve Finansal Okuryazarlığın Girişimcilik Eğilimi ile Arasındaki İlişkide Algılanan Sosyal Desteğin Aracılık Etkisi” Dumlupınar Üniversitesi Sosyal Bilimler Dergisi, Afro-Avrasya Özel Sayısı: 436, 419.

Tabachnick, Barbara G.; Fidell, Linda S. (2013), Using Multivariate Statistics, 6. baskı, Boston: Pearson.

Tarı, Recep (2015). Ekonometri. Kocaeli: Umuttepe Yayınları.

TDK (2019). Türk Dil Kurumu Sözlükleri. http://sozluk.gov.tr/(Erişim: 2018)

Temizel, Fatih; Bayram, Fatih (2011). “Finansal Okuryazarlık: Anadolu Üniversitesi İktisadi ve İdari Bilimler Fakültesi (iiBF) Öğrencilerine Yönelik Bir Araştırma”, Cumhuriyet Üniversitesi İktisadi ve İdari Bilimler Dergisi. C.12 S.1: 7386.

Yılmaz, Volkan; Varol, Semra (2015), “Hazır yazılımlar ile yapısal eşitlik modellemesi: AMOS, EQS, LISREL”, Dumlupınar Üniversitesi Sosyal Bilimler Dergisi, 44: 28-44. 


\section{Extended Summary}

\section{Relationship between Financial Literacy, Propensity to Take Risk and Tolerance of Ambiguity: A Research on Western Mediterranean Entrepreneurs}

The purpose of this research is to reveal whether entrepreneurs' who are operating in Western Mediterranean region financial literacy level is related to propensity to take risk and tolerance of ambiguity which are entrepreneurs' characteristics. In addition to this main purpose, the relationship between sub-dimensions of financial literacy level and entrepreneurs' characteristics which are propensity to take risk and tolerance of ambiguity will also be discussed. In the related literature, there is almost no study linking the characteristics of entrepreneurs with the level of financial literacy. So, it is thought that the study will make an important contribution to the related literature. The hypotheses created for this purpose are as follows.

H1: Entrepreneurs' financial information level will be related to propensity to take risk.

H2: Entrepreneurs' financial attitude level will be related to propensity to take risk.

H3: Entrepreneurs' financial behavior level will be related to propensity to take risk.

H4: Entrepreneurs' financial literacy level will be related to propensity to take risk.

H5: Entrepreneurs' financial information level will be related to tolerance of ambiguity.

H6: Entrepreneurs' financial attitude level will be related to tolerance of ambiguity.

H7: Entrepreneurs' financial behavior level will be related to tolerance of ambiguity.

H8: Entrepreneurs' financial literacy level will be related to tolerance of ambiguity.

Quantitative research methods were used to test these hypotheses. So, firstly data were collected using questionnaire. The questionnaire was consisted of three parts. In the first part; to measure the financial literacy level of entrepreneurs, "2015 OECD / INFE Toolkit for Measuring Financial Literacy and Financial Inclusion" created by OECD was used. In the second part of the questionnaire, entrepreneurs' propensity to take risk and tolerance of ambiguity were measured. The reason of selecting these two dimensions was that financial literacy contains risk, return and financial uncertainty. Accordingly, a total of 16 items that measure the propensity to take risk (7) and tolerance of ambiguity (9) developed by Koh (1996) and adapted to Turkish by Bozkurt (2005) were used. In this part, items were a five-point Likert-type scale. In the third and last part was consisted of questions about the demographic characteristics of the entrepreneurs and the companies they own.

The questionnaire was applied to the sampling selected in accordance with the purpose of the research. The research's population consisted entrepreneurs operating in the Western Mediterranean Region (Antalya, Burdur and Isparta) and registered in the trade chamber of these provinces. According to the data received from the chambers of commerce in 2018, there are 33,734 registered entrepreneurs in Antalya, 2,759 in Burdur and 5,706 in Isparta. While creating the sample, quota sampling method which is one of the non-probabilistic sample techniques was used. At the end, a total of 334 entrepreneurs which consist of 267 from Antalya, 23 from Burdur and 44 from Isparta participated. The questionnaires were applied to the participants through face-to-face, online and e-mail. Because of missing data, 10 questionnaires were excluded from the research. Hence, analyzes were carried out by including 324 questionnaires. When the demographic characteristics of the selected sample were examined, it was found that the number of men was higher than the number of women. Entrepreneurs in the range of 20-40 years old were more than half of the sample. Almost half of the participants were secondary school graduates. The majority of entrepreneurs operated their activity at the local level. Approximately half of the entrepreneurs participating in the study worked alone and $90 \%$ of them did not export. In addition, participants had little experience. Approximately $40 \%$ had less than 1 year of experience as an entrepreneur. $80 \%$ of the participants had an income below 5,000 TL and $70 \%$ were in the service sector. When asked about the age of the business they are currently working in, they reported that approximately $50 \%$ of firms have been operating for less than 5 years.

After obtaining the data, analyzes were carried out. In order to control data's distribution, skewness and kurtosis coefficients were examined and a sufficient match to the normal distribution was determined.

Before starting the hypothesis tests, the validity and reliability were tested. For this reason, the Cronbach Alpha Reliability Coefficients of the propensity to take risk and tolerance of ambiguity variables were checked separately. As a result, it was observed that the cronbach alpha value remained below 0,70 . In order to increase the reliability of the scale, two items were taken from the propensity to take risk dimension and one item from the tolerance of ambiguity dimension. After the transformation, cronbach alpha values were became desired level. 


\section{Eskişehir Osmangazi Üniversitesi IïBF Dergisi}

To test the validity of the scales, confirmatory factor analysis was used. Firstly, suitability of factor and homogeneity of items were checked. For this reason Kaiser-Meyer-Olkin (KMO) measure of sampling adequacy and Barlett's test were conducted and it was found that data suit to assumptions. Then, propensity to take risk and tolerance of ambiguity analyzed via AMOS 21 program. Eliminating three items from tolerance of ambiguity provided the validity of the findings.

Then, the data were analyzed via least squares method. According to the results of the analysis; financial literacy, financial information and financial attitude levels were positively related to propensity to take risk and tolerance of ambiguity which are entrepreneurship characteristics. So, it can be said that if financial literacy is related to propensity to take risk and tolerance of ambiguity positively, financial literacy may be related to number of entrepreneurs. This result was in parallel with the study of Seyrek and Gül (2017: 113-114), which shows the effect of financial literacy level on finding entrepreneurship attractive.

According to study, financial literacy level affected to propensity to take risk more than tolerance of ambiguity. According to this result, the increase in the level of financial literacy may improve the dominance of related field and cause individuals to take more and easier risks by analyzing the economic data better and making accurate predictions about the future. In addition, more financial literacy level means more the self-confidence, because of knowledge and success. So, rising in the self-confidence may be increase the tendency to turn the risk into an opportunity instead of retreating or giving up when an unexpected situation occurs in the economy.

In the research, an increase in the level of financial information and financial attitude also increased the propensity to take risk and tolerance of ambiguity, while the level of financial behavior did not have a significant effect on these variables. However, when beta values are analyzed, even if the level of financial behavior did not related to the propensity to take risk and tolerance of ambiguity significantly, the variables' directions were same.

As a result, the fact that financial literacy level related to propensity to take risk and tolerance of ambiguity makes think that it will have an impact on the number and success of entrepreneurial activities. Therefore, in the policies about increasing the number of enterprises may consider financial literacy. The literature about financial literacy may enhance in further researches. Two of entrepreneurship characteristics used in this study but researchers may examine all dimensions of entrepreneurship characteristics in the other studies or researchers may choose entrepreneurs who operating at Turkey as universe. 